\title{
Transgenic and conventional Brazilian soybeans don't cause or prevent preneoplastic colon lesions or oxidative stress in a 90-day in vivo study
}

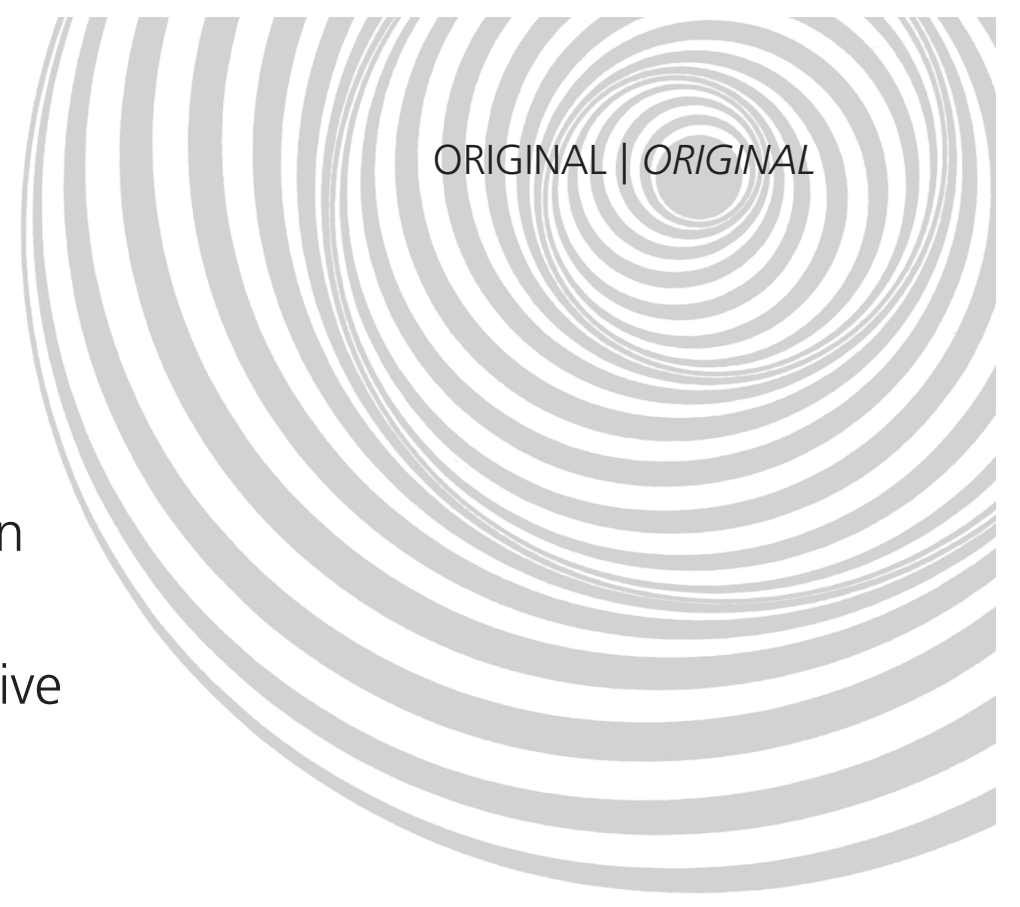

\section{Sojas transgênicas e convencionais brasileiras}

\author{
não causam ou previnem lesões \\ pré-neoplásicas ou stress oxidativo \\ em estudo in vivo de 90 dias
}

\author{
Felipe Augusto SBRUZZI ${ }^{1}$ \\ Vinícius de Paula VENÂNCIO² \\ Maria Cristina Costa RESCK ${ }^{2}$ \\ Maísa Ribeiro Pereira Lima BRIGAGÃO ${ }^{3}$ \\ Luciana AZEVEDO ${ }^{4}$
}

\section{A B S T R A C T}

\section{Objective}

The study presents the results of a 90-day safety assessment of rats fed with four varieties of soybeans, BRS 245 RR and BRS Valiosa RR (transgenic), BRS 133 and MG BR46 Conquista (non-transgenic).

\section{Methods}

Diets were prepared by incorporating toasted soybean flour to a commercial diet at $1 \%$, $10 \%$ or $20 \%$ weight In the in vivo experimental the rats' body weight, body weight gain, food consumption, number of aberrant crypt foci, oxidative stress biomarkers, urea and creatinine levels were analyzed and compared between experimental groups, as well as histopathological observations (digestive tract, liver, kidneys).

${ }^{1}$ Universidade Federal de Alfenas, Faculdade de Ciências Farmacêuticas. Alfenas, MG, Brasil.

${ }^{2}$ Universidade José do Rosário Vellano, Departamento de Medicina Veterinária. Alfenas, MG, Brasil.

3 Universidade Federal de Alfenas, Instituto de Ciências Exatas, Programa de Pós-Graduação em Ciências Cirúrgicas. Alfenas, MG, Brasil.

${ }^{4}$ Universidade Federal de Alfenas, Faculdade de Nutrição, Departamento de Nutrição. R. Gabriel Monteiro da Silva, 700, 37130-000, Alfenas, MG, Brasil. Correspondência para/Correspondence to: L AZEVEDO. E-mail: <luciana.azevedo@unifal-mg.edu.br> 
444 | FA SBRUZZI et al.

\section{Results}

The results indicate that glyphosate-tolerant soy varieties neither induce nor prevent aberrant crypt foci induction, nor do their conventional counterparts. Similarly, none of the four soybean varieties tested induced changes in the digestive tract, liver or kidney. Serum biochemical parameters were also unchanged.

\section{Conclusion}

The consumption of both, conventional and transgenic soybeans, were insufficient to ameliorate dimethylhydrazine-induced oxidative stress.

Indexing terms: Aberrant crypt foci. Colon carcinogenesis. Dimethlyhydrazine. Free radicals. Genetically Modified Organisms. Transgenic soybean.

\section{R E S U M O}

\section{Objetivo}

Este estudo apresenta os resultados de um experimento de 90 dias com o objetivo de avaliar a segurança de quatro variedades de grãos de soja: BRS 245 RR e BRS Valiosa RR (transgênicas), BRS 133 e MG BR46 Conquista (não transgênicas).

\section{Métodos}

As dietas foram preparadas incorporando farinha de grãos de soja à dieta comercial (FRI-LAB Ratos II) a 1\%, $10 \%$ ou $20 \% \mathrm{~m} / \mathrm{m}$. O peso corpóreo dos animais, o ganho de peso, o consumo de dieta, o número de focos de criptas aberrantes e os níveis de marcadores de estresse oxidativo, de creatinina e de ureia foram comparados entre os grupos experimentais, assim como as observações histopatológicas (trato digestivo, fígado e rins).

\section{Resultados}

Os resultados indicaram que as variantes glifosato-tolerantes não induziram ou preveniram a indução de focos de criptas aberrantes, assim como suas parentais convencionais. Similarmente, nenhuma das quatro variedades de grãos de soja testadas induziu alterações no trato digestivo, no fígado e nos rins. Os parâmetros bioquímicos do soro permaneceram também inalterados.

\section{Conclusão}

Tanto o consumo de grãos de soja convencionais quanto o de transgênicos foram ineficazes para melhorar os niveis de estresse oxidativo induzidos pela dimetilhidrazina.

Termos de indexação: Focos de criptas aberrantes. Carcinogênese de cólon. Dimetilhidrazina. Radicais livres. Organismo genéticamente modificados. Soja transgênica.

\section{INTRODUCTION}

According to the International Service for the Acquisition of Agri-Biotech Applications, during 2011, an additional 12 million hectares of biotech crops were cultivated, representing an annual growth rate of $8 \%$ percent over 2010 . Among them, the soybean stands out as the major biotech crop as Genetically Modified Organisms (GMO), occupying $75 \%$ of global adoption rates. In this setting, Brazil is the second largest world producer of soy, behind only the United States'. The increasing supply of transgenic soybeans and the great versatility of its use in many foods determine the growing consumption by the population. Despite the potential benefits of transgenic techniques, serious concerns have been raised related to the potential environmental and medical consequences of GMO use. The medical consequences, or risk factors, are generally assigned to health risks of conventional foods, including toxicity, allergenicity, antinutrition effects, unintended side-effects, the secondary effects of gene expression, and the disruption of the genetic material or metabolism of the consumer ${ }^{2}$. The risk of mutagenesis and modified gene expression or even cancer itself, in the long term, is the biggest fear of most populations. 
Safety assessment of genetically modified crops initially focuses on comparisons with the nearest isogenic relative using agronomic performance metric and compositional analysis to determine whether the particular genetic modification produces unintended effects ${ }^{3}$. Therefore, nutritional and safety assessments of GMO foods are one of the key measures that nutritionists can take to allay the fears of the public.

To assess carcinogenesis risk, parameters such as Aberrant Crypt Foci (ACF) can be evaluated. In numerous animal studies, ACF predicts subsequent development of colorectal cancer ${ }^{4}$. Furthermore, oxidative stress parameters are associated with cancer development and progression ${ }^{5}$. Colorectal tissue is regularly exposed to a variety of hazardous chemicals, and the Reactive Oxygen/Nitrogen Species (ROS/RNS) formed during the metabolic transformation of these compounds has been thought to play an important role in carcinogenesis ${ }^{6}$. Then, this study was designed to compare different contents of transgenic and conventional soybeans as potential colon lesion-inducing or protective agents. It was also explored whether the consumption of soybeans could ameliorate previously established colon lesions and associated oxidative damages.

\section{METHODS}

\section{Chemical reagents}

1,2-Dimethylhydrazine (DMH), 1,1,3,3Tetraethoxypropane (TEP), reduced GSH, Glutathione Desulfide (GSSG), glutathione reductase (E.C.1.6.4.2), $\beta$-Nicotinamide Adenine Dinucleotide Phosphate, reduced (NADPH), Monobromobimane $(\mathrm{mBr})$, guanidine and Buthylhydroxytoluene (BHT) were obtained from Sigma Aldrich Chemical Co. Methanol and acetic acid were purchased from J.T. Baker, Inc. All other reagents were analytical grade.

\section{Soybeans cultivars}

The following Brazilian soybeans were used: BRS 245 RR (Transgenic Soybean 1) and its most closely related non-transgenic strain, BRS133 (Conventional Soybean 1); also, MGBRS Valiosa RR (Transgenic Soybean 2) and its most closely related non-transgenic strain, MGBR46 Conquista (Conventional Soybean 2) were also evaluated.

Although all the soybeans were certified, a Roundup Ready test was conducted to confirm the presence or absence of the glyphosate resistant CP4-5-enolpyruvyls-hikimate-3phosphate-synthase (CP4 EPSPS) protein with the AgraStrip $^{\circledR}$ GMO RR test kit from Romer Labs ${ }^{\circledR}$.

\section{Diet preparation}

The diets used were prepared according to the following procedure: the soybeans ( $8 \%$ weight/weight - w/w moisture) were dehydrated in a cabinet dryer at $100^{\circ} \mathrm{C}, 30$ minutes. The dehydrated grains were ground in a mill with $0.5 \mathrm{~mm}$ mesh at approximately 3,000 $\mathrm{xg}$. The flour was then transferred back to the cabinet dryer for another $30 \mathrm{~min}$ (4\% w/W moisture). After these procedures, the dehydrated soy flour was mixed with a commercial diet at $1 \%, 10 \%$ or $20 \%(\mathrm{w} / \mathrm{W})^{7}$.

Compositional analysis of all the diets used was performed in triplicate. After the diet preparation, moisture was determined by loss while drying with an Infrared IV200 Moisture Analyzer for 8 minutes at $120^{\circ} \mathrm{C}$. Total nitrogen was analyzed by the Kjeldahl procedure (conversion factor was 6.25) and ash content was determined by incineration at $550^{\circ} \mathrm{C}$ in a muffle furnace. Total fat was estimated according to Bligh \& Dyer ${ }^{8}$ and the carbohydrates were calculated as the remainder (difference using the fresh weight-derived) ${ }^{9}$.

\section{Experimental Protocol and determination of ACF number}

The animals used in this study were handled in accordance with the Ethical Principles 
for Animal Research adopted by the Colégio Brasileiro de Experimentação Animal (COBEA, Brazilian College of Animal Experimentation). The protocol used herein was approved by the Universidade Federal de Alfenas, Minas Gerais Ethics Committee for Animal Research (94/2006). Two experiments were performed, being the first one designed to assess the activity of transgenic and conventional soybean on the modulation of preneoplastic lesion in colon (induction effect study). The second experiment was conducted to determine whether transgenic and conventional soy could be used to reduce the damage in the colon (chemopreventive test). For this purpose, rats were randomly distributed into 14 groups of 8 animals each for the induction effect study (Figure 1A) and the chemopreventive test (Figure $1 \mathrm{~B})$, during 13 weeks. The inducting drug, $\mathrm{DMH}$, was dissolved in $0.9 \%$ weight/volume(w/v) $\mathrm{NaCl}$ immediately before use. The $0.9 \%(\mathrm{w} / \mathrm{v}) \mathrm{NaCl}$ and DMH were given in 2 doses of $40 \mathrm{mgkg}^{-1}$ b.w. for week, during 2 weeks. For both experiment, groups 1 (negative control groups) received commercial diet for the entire experimental period and groups 2 (positive control groups) received commercial diet and $\mathrm{DMH}$. The experimental groups received diets containing different

A

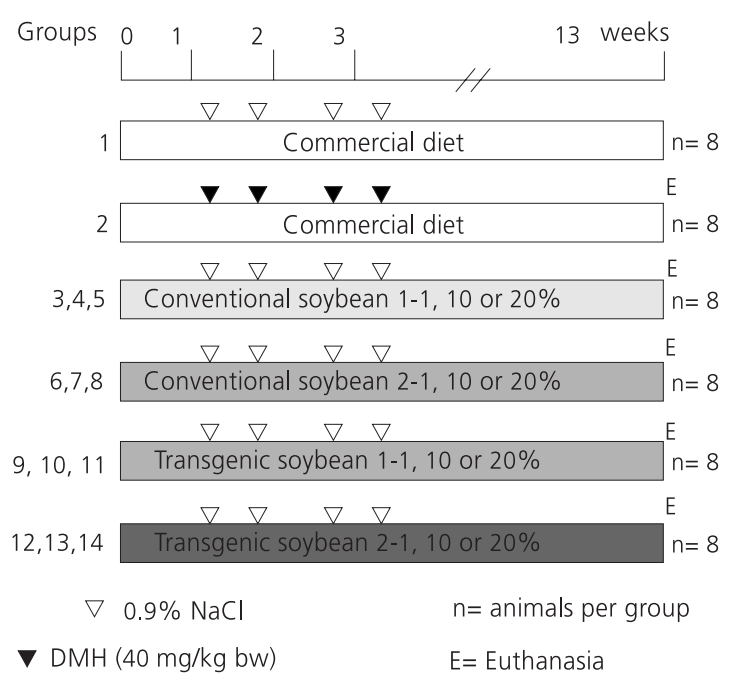

soybeans types and concentrations throughout the experimental period.

For Aberrant Crypt Foci analysis, the colons were obtained, stained with methylene blue and analyzed according to Fenoglio-Preiser \& Noffsinger ${ }^{4}$. Fifty sequential fields on $40 \times$ magnification of the distal colon were screened for ACF, which were distinguished by an elongated, slit-shaped lumen surrounded by thickened epithelium that stained more intensively than the surrounding normal crypts. The number of ACF and the number of Aberrant Crypts (AC) in the distal colon were recorded.

\section{Biochemical parameters}

For the oxidative stress determination, the serum containing $0.05 \%$ BHT was quickly frozen until MDA (Malonaldhyde) analysis. Samples were chromatographed after standard preparation according to Brown \& Kelly ${ }^{10}$. Fluorimetric detection was performed $\left(\lambda_{\text {ex }} 532 \mathrm{~nm}, \lambda_{\text {em }} 553 \mathrm{~nm}\right)$ and peak of Malondialdehyde-Thiobarbituric Acid (MDA-TBA) adduct was calibrated with 97\% (v/V) TEP.

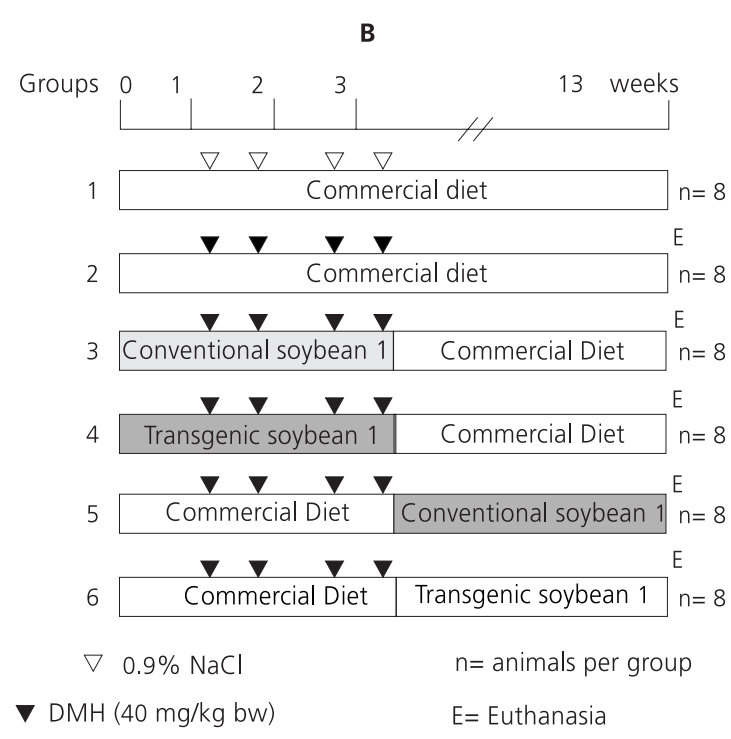

Figure 1. Protocols for $(A)$ the inductive effect experiment of soybeans and $(B)$ the chemopreventive experiment of soybeans in colon carcinogenesis. 
Protein Carbonyl (PC) was measured by the formation of protein hydrazone derivatives from the reaction with Dinitrophenylhydrazine (DNPH), which were quantified spectrophotometrically. Separate blanks were prepared without DNPH and the carbonyl ${ }^{11}$ content was determined from the equation $\varepsilon_{370 \mathrm{~nm}}=22,000 \mathrm{M}^{-1} \mathrm{~cm}^{-1}$.

GSH and other thiols react with $\mathrm{mBrB}, \mathrm{a}$ sulfhydryl-alkylating agent. To investigate possible changes in the level of GSH resulting from soy ingestion and $\mathrm{DMH}$ treatment, thiol adducts with $\mathrm{mBrB}$ were separated by Hight-Performace Liquice chromatography (HPLC) ${ }^{12}$. GSH was identified by comparison to the retention times of authentic standards as measured by fluorescence detector $\left(\lambda_{\text {ex }} 360 \mathrm{~nm}, \lambda_{\mathrm{em}} 470 \mathrm{~nm}\right)$ and its quantification was performed through integral analysis of areas. GSSG content was determined through treatment with GSSG reductase coupled with NADPH. Its stoichiometry with GSH was calculated and expressed as the ratio GSH (GSH+0.5 GSSG) ${ }^{-1}$. All parameters were standardized for total protein content ${ }^{13}$.

The creatinine and urea levels were determined in all samples by routine spectrophotometric methods with compoundspecific kits (BioTecnica ${ }^{\circledR}$ ).

\section{Histopathological analysis}

Sections of each lobe of the liver, small intestine and stomach were taken immediately after animal euthanasia. The tissues were fixed in buffered $4 \%(\mathrm{v} / \mathrm{v})$ formaldehyde for 24 hous, dehydrated in graded ethanol and embedded in paraffin. Thin sections $(5 \mu \mathrm{m})$ were obtained, stained with hematoxylin-eosin and examined microscopically for histological changes.

\section{Statistical analysis}

The body weight, weight gain, food consumption measured weekly and centesimal composition were analyzed by Analysis of
Variance (Anova). The total number of $A C F$, number of $A C$ per focus and the relationship between crypt/FCA in the different groups were analyzed by the Kruskal-Wallis test. Two-way Anova was used to compare serum oxidative stress parameters between groups.

For statistical analyses, $p$ values equal to or lower than 0.05 were considered statistically significant.

\section{RE S U L T S}

The transgenic grains, flours and diets were positive for the CP4 EPSPS protein and the conventional products were negative for this protein. This analysis confirmed the certified origin of the grains and, importantly, that the conventional soybeans were GMO free. The centesimal composition of the experimental diets demonstrated that the diets with the same percentages of soybeans were similar to each other regardless of whether they contained transgenic or conventional soybeans, as shown in Table 1.

In both experiments, differences in body weight, weight gain and food consumption were observed during the $\mathrm{DMH}$ injection period, but by the end of the experiment, the induced groups did not show any differences from other groups.

The body weight gain ranged between $290 \pm 31 \mathrm{~g}$ and $333 \pm 19 \mathrm{~g}$ in the induction effect study, and between $259 \pm 28 \mathrm{~g}$ and $298 \pm 30 \mathrm{~g}$ in the chemopreventive test. The consumption of all soybean cultivars, transgenic or not, was very similar in both experiments. On this way, the average daily consumption of soybean in the groups that received diet at $1 \%, 10 \%$ or $20 \%$ (w/w) soybeans was $1 \pm 0 \mathrm{~g} / \mathrm{kg}^{-1}$ b.w., $9 \pm 3 \mathrm{~g} / \mathrm{kg}^{-1}$ b.w. and $18 \pm 6 \mathrm{~g} / \mathrm{kg}^{-1}$ b.w., respectively.

In the induction effect study only the positive group showed $A C F$, counting $6 \pm 3$ for the total number of $A C F$, and $2 \pm 0$ for the total number of $A C$ and Crypt/ACF. The numbers of $A C F$ and crypt multiplicity in the colon from 
448 | FA SBRUZZl et al.

Table 1. Compositional equivalence of the studied diets in $\mathrm{g} / \mathrm{kg}^{-1 *}$.

\begin{tabular}{|c|c|c|c|c|c|c|c|c|c|c|c|}
\hline \multirow{2}{*}{ Diet } & \multirow{2}{*}{ Soybeans (\%) } & \multicolumn{2}{|c|}{ Fat } & \multicolumn{2}{|c|}{ Protein } & \multicolumn{2}{|c|}{ Ash } & \multicolumn{2}{|c|}{ Moisture } & \multicolumn{2}{|c|}{ Carbohydrate } \\
\hline & & $\mathrm{M}$ & SD & $\mathrm{M}$ & SD & $\mathrm{M}$ & SD & M & SD & $\mathrm{M}$ & SD \\
\hline Commercial Diet & - & 40.3 & 2.5 & 229.0 & 0.8 & 78.4 & 0.8 & 111.7 & 3.1 & 541.0 & 4.0 \\
\hline \multirow[t]{3}{*}{ Conventional soybean 1} & 1 & 40.2 & 0.2 & 233.9 & 1.4 & 84.8 & 0.5 & 114.7 & 2.5 & 527.0 & 3.0 \\
\hline & 10 & 50.9 & 0.7 & 250.6 & 2.6 & 78.0 & 2.7 & 127.7 & 2.9 & 493.0 & 5.0 \\
\hline & 20 & 66.0 & 1.7 & 268.4 & 2.6 & 72.9 & 0.3 & 124.7 & 3.8 & 468.0 & 5.0 \\
\hline \multirow[t]{3}{*}{ Transgenic soybean 1} & 1 & 39.8 & 1.0 & 234.4 & 1.3 & 83.8 & 2.5 & 128.7 & 2.1 & 513.0 & 4.0 \\
\hline & 10 & 53.0 & 2.6 & 256.7 & 0.5 & 75.9 & 2.1 & 124.3 & 1.5 & 490.0 & 4.0 \\
\hline & 20 & 62.4 & 3.0 & 273.1 & 2.1 & 73.2 & 0.4 & 125.7 & 2.1 & 466.0 & 4.0 \\
\hline \multirow[t]{3}{*}{ Conventional soybean 2} & 1 & 41.0 & 1.0 & 235.1 & 1.2 & 82.9 & 0.3 & 116.7 & 4.7 & 524.0 & 5.0 \\
\hline & 10 & 52.9 & 3.1 & 257.9 & 1.2 & 78.8 & 2.4 & 126.7 & 2.3 & 485.0 & 5.0 \\
\hline & 20 & 63.1 & 2.5 & 273.1 & 2.0 & 73.5 & 0.4 & 118.0 & 3.5 & 472.0 & 5.0 \\
\hline \multirow[t]{3}{*}{ Transgenic soybean 2} & 1 & 39.4 & 1.3 & 234.0 & 4.2 & 84.8 & 1.6 & 119.3 & 2.1 & 522.0 & 4.0 \\
\hline & 10 & 54.7 & 3.4 & 254.9 & 2.7 & 76.9 & 0.3 & 121.0 & 5.2 & 522.0 & 4.0 \\
\hline & 20 & 65.4 & 2.6 & 268.5 & 2.2 & 70.8 & 1.9 & 109.3 & 3.2 & 486.0 & 5.0 \\
\hline
\end{tabular}

Note: *Values are given as Mean (M) \pm Standard Deviation (SD). No statistical difference among diets with the same soybean content.

Table 2. Chemopreventive test: Lack of anticarcinogenicity of a soybean-containing diet on aberrant crypt foci formation and crypt multiplicity (crypt/ACF) in colon ${ }^{a}$.

\begin{tabular}{|c|c|c|c|c|c|c|}
\hline \multirow{2}{*}{ Group/Treatment ${ }^{b}$} & \multicolumn{2}{|c|}{ Total $n^{\circ}$ ACF } & \multicolumn{2}{|c|}{ Total $n^{\circ} A C$} & \multicolumn{2}{|c|}{ Crypt/ ACF } \\
\hline & M & SD & M & SD & $M$ & SD \\
\hline Commercial diet $+\mathrm{NaCl}$ & 1 & $2^{+}$ & 1 & $4^{+}$ & 0 & $1^{\dagger}$ \\
\hline Commercial diet + DMH & 16 & 8 & 34 & 17 & 2 & 1 \\
\hline Conventional soybean $1+\mathrm{DMH}$ & 10 & 5 & 27 & 14 & 3 & 1 \\
\hline Transgenic soybean $1+\mathrm{DMH}$ & 10 & 8 & 25 & 18 & 2 & 1 \\
\hline DMH + Conventional soybean 1 & 11 & 7 & 26 & 19 & 2 & 1 \\
\hline DMH + Transgenic soybean 1 & 13 & 3 & 29 & 8 & 2 & 1 \\
\hline
\end{tabular}

Note: aValues are given as mean (M) \pm Standard Deviation (SD). ${ }^{\mathbf{b}} 0.9 \% \mathrm{NaCl}\left(0.1 \mathrm{~mL} 10 \mathrm{~g}^{-1}\right.$ b.w.); DMH: 1,2-dimethylhydrazine (4×40 mg/kg ${ }^{-1}$ b.w.). ${ }^{\dagger} p<0.05$ (Kruskal-Wallis): the negative control group was statistically different from the other groups; AC: Aberrant Crypts; ACF: Aberrant Crypt Foci.

different groups of chemopreventive experiment are summarized in Table 2 . The results show that all DMH-initiated animals developed ACF by the $13^{\text {th }}$ week of the experiment.

Lipid peroxidation and protein oxidation biomarkers revealed that $\mathrm{DMH}$ is an oxidative stress inductor (Tables 3 and 4). Typical chromatograms obtained from the MDA-TBA adduct showed an average retention time of $5.53 \mathrm{~min}$. The basal lipid peroxidation level detected in serum samples was $12.9 \pm 0.8 \mathrm{nmol}$ MDA $\mathrm{mg}^{-1}$ protein, while DMH-treated animals showed roughly doubled concentrations of MDA. Also, oxidative damage to protein structure is evident in DMH-treated animals; PC levels of
DMH-treated animals increased nearly twice as much as those of control group. However, the ratio of GSH (GSH+0.5 GSSG) ${ }^{-1}$ detected in serum samples as GSH-mBrB adduct (retention time 12.96 minutes) was not altered by $\mathrm{DMH}$ treatment. The mean value of this ratio was $0.25 \pm 0.02$, clearly indicating that no GSH oxidation or consequent GSSG accumulation occurred in serum samples under these experimental conditions.

From the same data, it is clear that soybeans ingestion was unable to induce or prevent oxidative damage in lipid and serum structures, or to modify redox serum status. 
Table 3. Effect of soybean consumption on oxidative stress parameters ${ }^{1}$.

\begin{tabular}{|c|c|c|c|c|c|c|c|}
\hline \multirow{2}{*}{ Group/treatment ${ }^{b}$} & \multirow{2}{*}{ Soybeans (\%) } & \multicolumn{2}{|c|}{ nmol MDA mg protein ${ }^{-1}$} & \multicolumn{2}{|c|}{ nmol PC mg protein ${ }^{-1}$} & \multicolumn{2}{|c|}{ Ratio GSH (GSH + 0.5 GSSG) $)^{-1}$} \\
\hline & & $M$ & SD & $M$ & SD & $M$ & SD \\
\hline Commercial diet + DMH & - & 24.8 & $3.9^{\dagger}$ & 19.2 & $2.1^{\dagger}$ & 0.199 & 0.128 \\
\hline Commercial diet & - & 12.9 & 0.8 & 8.7 & 1.6 & 0.289 & 0.028 \\
\hline \multirow[t]{3}{*}{ Conventional soybean 1} & 1 & 14.2 & 0.7 & 8.4 & 0.9 & 0.309 & 0.018 \\
\hline & 10 & 16.4 & 0.5 & 7.7 & 2.4 & 0.254 & 0.108 \\
\hline & 20 & 11.9 & 0.4 & 7.3 & 71.1 & 0.314 & 0.020 \\
\hline \multirow[t]{3}{*}{ Conventional soybean 2} & 1 & 12.1 & 0.8 & 6.9 & 2.6 & 0.239 & 0.021 \\
\hline & 10 & 13.5 & 0.7 & 8.4 & 1.1 & 0.319 & 0.108 \\
\hline & 20 & 15.6 & 0.3 & 8.7 & 1.6 & 0.244 & 0.088 \\
\hline \multirow[t]{3}{*}{ Transgenic soybean 1} & 1 & 17.9 & 0.8 & 9.3 & 1.0 & 0.310 & 0.029 \\
\hline & 10 & 12.9 & 0.7 & 8.2 & 0.6 & 0.235 & 0.021 \\
\hline & 20 & 15.9 & 0.5 & 9.7 & 1.9 & 0.307 & 0.037 \\
\hline \multirow[t]{3}{*}{ Transgenic soybean 2} & 1 & 12.9 & 0.7 & 9.3 & 2.6 & 0.294 & 0.480 \\
\hline & 10 & 16.9 & 0.8 & 8.9 & 1.0 & 0.314 & 0.020 \\
\hline & 20 & 11.9 & 0.9 & 9.6 & 1.4 & 0.239 & 0.021 \\
\hline
\end{tabular}

Note: ${ }^{\dagger} p<0.05$ (Two-way Anova): The DMH-treated group (1,2-dimethylhydrazine; $4 \times 40 \mathrm{mg} / \mathrm{kg}^{-1} \mathrm{~b}$.w.) was statistically different from the other

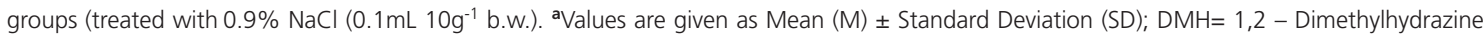
$\left(4 \times 40 \mathrm{mg} / \mathrm{kg}^{-1}\right.$ b.w.)

MDA: Malondialdehyde; PC: Protein Carbonyl; GSH: Glutathione; GSSG: Glutathione Disulfide.

Table 4. The effect of combined DMH treatment and soybeans diet on serum oxidative stress biomarkers ${ }^{\mathrm{a}}$.

\begin{tabular}{|c|c|c|c|c|c|c|}
\hline \multirow{2}{*}{ Group/treatment ${ }^{\mathbf{b}}$} & \multicolumn{2}{|c|}{ nmol MDA mg protein ${ }^{-1}$} & \multicolumn{2}{|c|}{ nmol PC mg protein ${ }^{-1}$} & \multicolumn{2}{|c|}{ Ratio GSH (GSH + 0.5 GSSG) } \\
\hline & $\mathrm{M}$ & SD & M & SD & M & SD \\
\hline Commercial diet $+\mathrm{NaCl}$ & 12.9 & $0.8^{*}$ & 8.7 & $1.6^{*}$ & 0.289 & 0.028 \\
\hline Commercial diet + DMH & 24.8 & 3.9 & 19.2 & 2.1 & 0.199 & 0.128 \\
\hline Conventional soybean $1+\mathrm{DMH}$ & 22.9 & 4.2 & 18.3 & 4.1 & 0.209 & 0.068 \\
\hline Transgenic soybean 1 + DMH & 27.9 & 3.4 & 18.7 & 3.6 & 0.259 & 0.880 \\
\hline DMH + Conventional soybean 1 & 25.9 & 1.9 & 19.3 & 5.1 & 0.214 & 0.020 \\
\hline DMH + Transgenic soybean 1 & 31.1 & 2.7 & 17.7 & 4.6 & 0.189 & 0.171 \\
\hline
\end{tabular}

Note: ${ }^{\dagger} p<0.05$ (Two-way Anova): The negative control group was statistically different from the other groups.

avalues are given as mean $\pm \mathrm{SD}$; ${ }^{\mathrm{b}} 0.9 \% \mathrm{NaCl}(\mathrm{w} / \mathrm{w})\left(0.1 \mathrm{~mL} 10 \mathrm{~g}^{-1}\right.$ b.w.); $\mathrm{DMH}=1$,2-dimethylhydrazine $\left(4 \times 40 \mathrm{mg} \cdot \mathrm{kg}^{-1}\right.$ b.w. $)$.

Neither creatinine nor urea serum levels were altered by DMH treatment or the soybeans diet. Creatinine, a normal product from metabolic creatine breakdown, was detected at a mean value of $0.46 \pm 0.018 \mathrm{mg} / \mathrm{dL}^{-1}$, and serum urea was detected at $41.56 \pm 12.8 \mathrm{mg} / \mathrm{dL}^{-1}$. Both biochemical markers were good indicators that renal function was unaltered in the animals.

Liver, kidney, small intestine, pancreas and stomach histopathological analysis indicated that none of the soybeans-based diets were toxic to these organs. No congestion, edema, cellular reactions (lymphocytic infiltration), cell degeneration or necrosis were observed in any of the analyzed tissues (data not shown).

\section{DISCUSSION}

Kok et al. ${ }^{14}$ state that new protein and other types of expression products or metabolites that have been introduced into new plant varieties and are not already part of the human diet should be 
assessed for their safety to the human consumer. The essence of this approach is that the new food (or component thereof) should be compared with appropriate conventional strain that is already accepted as safe based on its history as food ${ }^{15}$.

However, in spite of the inquiries associated with GMO, soy could be classified as a putative chemopreventive due to the allegations about its functional properties associated with health-promoting phytochemicals, which have antioxidant activities. According to Zeiger ${ }^{16}$ on the other hand, many substances reported to be antimutagens or anticarcinogens have themselves been shown to be mutagenic, carcinogenic or oxidant in many systems. Considering these factors, the present study was performed to investigate the safety and potential anticarcinogenic properties of transgenic soybean flours, in comparison to their nearest conventional counterparts. We investigated its ability to either induce or prevent ACF, histological lesions and serum oxidative stress parameters. Additional priority has to be given to measuring biomarkers of general oxidative changes correlated with the initiation and progression of the targeted cancer.

Despite the substantial equivalence principle, unintended adverse effects in edible fractions of Genetically Modified (GM) crops may occur even if they were not identified in composition or agronomic studies ${ }^{17}$. To address this possibility, animal feeding studies have been conducted with foods obtained from GM crops to determine whether they result in unintended deleterious nutritional changes. Meanwhile, the results of our study show that no biologically meaningful differences occur in the in vivo nutritional response variables of body weight, body weight gain and food consumption when comparing the testing groups to negative controls and when comparing groups with the same concentration of soybeans in the diet. These response variables serve as a sensitive indicator of general animal well being ${ }^{3}$. These results suggest that, under our experimental conditions, the four varieties of soy (two conventional and two transgenic) were nutritionally equivalent, providing evidence that the transgenic strains did not have cause unintended deleterious nutritional changes in the animals. This nutritional equivalence also confirms studies that substituting $11 \%$ and $33 \%$ of the diet with soy will not cause significant nutritional changes in rodents ${ }^{18}$.

Our results further showed that neither transgenic nor conventional soybeans diets stimulated or suppressed the development of ACF and crypt multiplicity at any of the levels tested. In the chemopreventive test (Table 2), we also evaluated whether transgenic and conventional soy can modify carcinogenesis before and after induction with carcinogen treatment. This was based on the knowledge of cancer development: cancer preventative agents can be classified based on their ability to affect preneoplastic lesions of different stages either before or after the carcinogen treatment. Furthermore, beneficial effects for health have been found for soy isoflavones, proteins and fibers ${ }^{19,20}$. Conversely, Omar et al. ${ }^{21}$ also observed that soybean flour enhanced carcinogenesis and promoted the progression of established neoplasms; in a second study ${ }^{22}$, an increase in tumors were reported in DMH-treated rats fed genistein.

Histopathological analyses of the digestive tract and the ACF observations revealed no evidence of lesions in soy-fed rats compared to the negative control group. Identical results were observed in the liver and kidneys, which are the main biotransformation and excretion organs. These data reinforce the idea that diets containing conventional or transgenic soybeans were not able to promote or prevent tissue injury.

Among biochemical pathways that mediate cancer, oxidative injury has been suggested as a relevant mechanism for damage that might contribute to neoplasia, a common final consequence related to this pathology. As MDA is one of the major secondary oxidation products derived from polyunsaturated fatty acids, its measurement has been regarded as a reflection 
of the lipid peroxidation level. This oxidative process generates a complex variety of products, many of them reactive electrophiles. These products can react with protein and DNA, causing toxicity and mutagenicity ${ }^{23}$. As shown in Table 3, $\mathrm{DMH}$ induced a significant increase in MDA serum levels (about 2-fold), presenting strong evidence that this carcinogenic substance causes lipid damage in parallel with the occurrence of preneoplastic lesions. A study in humans conducted by Spadafranca et al..$^{24}$ demonstrates that after 42 days of soy diet ( $80 \mathrm{mg} \mathrm{day}^{-1}$ of isoflavones) no significant effect on MDA level was observed. Other reports have found antioxidant effects attributable to soy isoflavones or other compounds present in this grain ${ }^{25}$. In our experiment, neither the conventional soybeans nor the transgenic ones had any impact on MDA levels (Table 4).

Protein oxidation results from ROS/RNS attack on protein structures, leading to a variety of structural and functional damage, which can be measured through DNPH adduction. Consistent with oxidative stress induced by $\mathrm{DMH}$, about 2.2 times more PC was detected in serum of animals submitted to $\mathrm{DMH}$ treatment than in control animals (Table 3). Soybean ingestion was incapable of decreasing or preventing a rise in this serum biomarker (Table 4).

GSH primarily functions as a non-enzymatic reducing agent, preventing oxidative stress in most cells and body fluids, and helping to trap ROS/RNS that can damage lipids, proteins, carbohydrates and nucleic acids. There is a direct correlation between the ratio of reduced glutathione/total glutathione and the redox state of the organism because GSH is converted to GSSG when an oxidative environment predominates over the antioxidant capability of the cells $s^{5}$. In concordance with the two other oxidant biomarkers, MDA and PCO, the GSH parameter was the same in animals fed with conventional or transgenic soybeans and no statistical difference is observed when compared to control groups (Table 3 and 4).
The lack of anticarcinogenic effect of soy in the tested situations may be explained by several conditions. First of all, the primary location of action of any orally administrated compound is the digestive tract. Later, the effects of absorption and distribution and the impacts on individual organs can be observed, and, finally, the kinetics of metabolism and excretion may have effects on the body ${ }^{26,27}$. The effects of chemopreventive dietary constituents are under the direct influence of the food matrix and their technological processing ${ }^{28}$, once these factors may affect their interaction with intestinal biotransformation enzymes ${ }^{26}$. It is possible that bioactive soybean compounds could not exert their chemopreventive effects due to absorption in the small intestine, which would not allow a substantial amount to reach the lumen of the colon and prevent preneoplastic lesions in loco. It is also possible that the ingested compounds were not bioavailable or that they did not have any effect on colon carcinogenesis. It is also important to consider that the intestinal microbiota is variable in different animal conditions, and different microorganisms may have diverse abilities to generate bioactive compounds from isoflavones and other compounds found in foods ${ }^{29}$.

\section{CONCLUSION}

Taken together, our results support the conclusion that neither BRS 245 RR nor BRS Valiosa RR transgenic soybeans stimulated or suppressed the development of ACF and crypt multiplicity, as well as non-transgenic grains, and show that soy antioxidant phytochemicals are unable to protect against dimethlyhydrazineinduced lipid and protein oxidative damage.

\section{A C KNOWLEDGEMENT}

The authors would like to thank Empresa Brasileira de Pesquisa Agropecuária, Loja São José 
452 FA SBRUZZl et al.

Sementes de Soja and Certrim for providing the soybean cultivars. This work was supported by Fundação de Apoio à Pesquisa do Estado de Minas Gerais. Felipe Augusto Sbruzzi was recipient of a fellowship of Conselho Nacional de Desenvolvimento Científico e Tecnológico.

\section{CONTRIBUTORS}

FA SBRUZZI contributed in the data obtaining, analysis and interpretation and in the manuscript writing. VP VENANCIO contributed in the data analysis and interpretation and also in the manuscript writing. MCC RESCK contributed in the execution and interpretation of histopathological analysis. MPRL BRIGAGÃO contributed in the execution and interpretation of oxidative stress analysis, in addition to the manuscript writing. L AZEVEDO contributed to the study design, data analysis and manuscript writing.

\section{REFERE N CES}

1. James C. Global status of commercialized biotech/ GM crops: 2011. ISAAA Brief $n^{\circ} 43 / 2011$. Ithaca (NY): International Service For the Acquisition of Agri-Biotech Applications; 2012.

2. Deng PJ, Zhou XY, Yang DY, Hou HL, Yang XK, Li $\mathrm{YH}$, et al. The definition, source, manifestation and assessment of unintended effects in genetically modified plants. J Sci Food Agric. 2008; 88:2401-13.

3. Appenzeller LM, Munley SM, Hoban D, Sykes GP, Malley L. Subchronic feeding study of herbicidetolerant soybean DP-356ø43-5 in Sprague-Dawley rats. Food Chem Toxicol. 2008; 46(6):2201-13.

4. Fenoglio-Preiser CM, Noffsinger A. Aberrant crypt foci: A review. Toxicol Pathol. 1999; 27(6):632-42.

5. Halliwell B, Gutteridge JMC. Free radicals in biology and medicine. New York: Oxford University Press; 2007.

6. Babbs CF. Free radicals and etiology of colon cancer. Free Radic Biol Med. 1990; 8(2):191-200.

7. Azevedo L, Dragano NRV, Sabino APL, Resck MCC, Alves de Lima PL, Gouvêa CMCP. In Vivo antimutagenic properties of transgenic and conventional soybeans. J Med Food. 2010; 13(6):1402-08.

8. Bligh EG, Dyer WJ. A rapid method of total lipid extraction and purification. Can J Biochem Physiol. 1959; 37:911-17.
9. Association of Official Analytical Chemists. Official methods of analysis. Washington (DC): AOAC; 2000.

10. Brown RK, Kelly FJ. Peroxides and other products. In: Punchard NA, Kelly FJ, editors. Free radicals: A practical approach. New York: IRL Press; 1996.

11. Reznick AZ, Packer L. Oxidative damage to proteins, spectrophotometric method for carbonyl assay. Method Enzymol. 1994; 233:357-63.

12. Anderson ME. Glutathione. In: Punchard NA, Kelly FJ, editors. Free radicals: A practical approach. New York: IRL Press; 1996.

13. Bradford MM. A rapid and sensitive method for quantification of microgram quantities of protein utilizing the principle of protein-dye binding. Anal Biochem. 1976; 72:248-54.

14. Kok EJ, Keijer J, Kleter GA, Kuiper HA. Comparative safety assessment of plant-derived foods. Regul Toxicol Pharmacol. 2008; 50(1):98-113.

15. Paoletti C, Flamm E, Yan W, Meek S, Renckens S, Fellous $\mathrm{M}$, et al. GMO risk assessment around the world: Some examples. Trends Food Sci Tech. 2008; 19(Suppl 1):S66-S74.

16. Zeiger E. What is needed for an acceptable antimutagenicity manuscript? Mutat Res. 2007; 626(1-2):1-3

17. Smallwood M. The impact of genomics on crops for industry. J Sci Food Agric. 2006; 86(12):1747-54.

18. Hammond B, Lemen J, Dudek R, Ward D, Jiang C, Nemeth $M$, et al. Results of a 90-day safety assurance study with rats fed grain from corn rootworm-protected corn. Food Chem Toxicol. 2006; 44(2):147-60.

19. Aguiar CL, Baptista AS, Alencar SM, Haddad R, Eberlin MN. Analysis of isoflavonoids from leguminous plant extracts by RPHPLC/DAD and electrospray ionization mass spectrometry. Int J Food Sci Nutr. 2007; 58(2):116-24.

20. Badger TM, Ronis MJJ, Simmens RCM, Simmen FA. Soy protein isolate and protection against cancer. J Am Coll Nutr. 2005; 24(2):146S-9S.

21. Omar RM, Ismail HM, El-Lateef BMA, Yousef MI, Gomaa NF, Sheta M. Effect of processing on folic acid fortified baladi bread and its possible effect on the prevention of colon cancer. Food Chem Toxicol. 2009; 47(7):1626-35.

22. Gee JM, Noterborn HPJM, Polley ACJ, Johnson IT. Increased induction of aberrant crypt foci by 1,2-dimethylhydrazine in rats fed diets containing purified genistein or genistein-rich soya protein. Carcinogenesis. 2000; 21(12):2255-9. 
23. Griffiths HR, Moller L, Bartosz G, Bast A, BertoniFreddari C, Collins A, et al. Biomarkers: Review. Mol Aspects Med. 2002; 23:101-208.

24. Spadafranca A, Erba D, Foti P, Testolin G. The consumption of soy products positively affects DNA resistance to oxidative stress in healthy subjects. Nutr Metab Cardiovas. 2008; 18(9):e45-e6.

25. Lee CH, Yang L, Xu JZ, Yeung SYV, Huang Y, Che ZY. Relative antioxidant activity of soybean isoavones and their glycosides. Food Chem. 2005; 90(4):735-41.

26. Hodek P, Krizková J, Burdová K, Sulc M, Kizek R, Hudecek J, et al. Chemopreventive compounds: View from the other side. Chem Biol Interact. 2009;180(1):1-9.
27. Hooper L, Cassidy A. A review of the health care potential of bioactive compounds. J Sci Food Agric. 2006; 86(12):1805-13.

28. Teresa SP, Hallund J, Talbot D, Schroot J, Williams CM, Bugel $\mathrm{S}$, et al. Absorption of isoflavones in humans: Effects of food matrix and processing. J Nutr Biochem. 2006; 17(4):257-64.

29. Davis CD, Milner JA. Gastrointestinal microflora, food components and colon cancer prevention. J Nutr Biochem. 2009; 20(10):743-52.

Received on: 28/8/2012

Final version on: $2 / 1 / 2013$

Approved on: 1/3/2013 
